\title{
Analisis Nilai Pengalaman Berbelanja Online Melalui Experiential Marketing
}

\author{
Agus Rahayu, Lili Adi Wibowo dan Christianingrum \\ Program Studi Magister Manajemen Bisnis, Universitas Pendidikan Indonesia \\ Syifa.meira@yahoo.com
}

\begin{abstract}
Abstrak
Kondisi ekonomi global Dunia sedang mengalami penurunan. Penurunan kondisi global tidak membawa perubahan besar bagi Indonesia. BPS menyatakan bahwa perekonomian Indonesia tumbuh dan akan terus meningkat selama Tahun 2012. Perkembangan kondisi global Indonesia ini mengakibatkan negara-negara maju mulai tertarik untuk melakukan investasi di Indonesia. Alasannya ialah pertumbuhan ekonomi yang baik dan lanskap penggunaan internet di Indonesia sedang mengalami perkembangan yang baik, sehingga mengembangkan dan menginvestasikan dana yang dimiliki akan memungkinkan pertumbuhan ekonomi negaranya menjadi lebih baik. Meningkatnya penggunaan internet membuat perubahan besar, banyak industri offline mulai beralih ke online. Ini menimbulkan permasalahan tersendiri bagi situs-situs perdagangan yang ada. Situs yang sedang berkembang adalah Tokobagus dan Tokopedia. Salah satu upaya yang dilakukan untuk menciptakan keputusan pembelian adalah dengan memberikan penawaran terbaik bagi konsumen dengan memberikan pengalaman yang unik dan berkesan. Pengalaman pelanggan dapat diciptakan dengan experiential marketing. Schmitt(1999) mengemukakan bahwa experiential marketing akan bisa menciptakan experience. Experience yang positif akan mampu menciptakan keputusan pembelian. Responden dalampenelitian ini adalah pembeli di situs Tokobagus dan Tokopedia. Metode yang digunakan adalah explanatory survey dan deskriftif survey. Hipotesis dari penelitian ini adalah terdapat pengaruh positif antara penciptaan nilai pengalaman berbelanja online melalui experiential marketing terhadap keputusan pembelian, Untuk mengukur pengaruh variabel tersebut digunakan metode partial least square. Dari hasil penelitian experiential marketing yang dilaksanakan melalui dimensi sense, feel, think, actdan relate memiliki pengaruh yang positif untuk menciptakan nilai pelanggan dan signifikan terhadap keputusan pembelian. Hal yang perlu ditingkatkan Tokobagus dan Tokopedia yaitu dengan memperbaiki design dan tampilan situs supaya lebih menarik perhatian, sehingga bisa merangsang emosi seseorang dan menimbulkan keinginan untuk membeli produk. Tampilan sebaiknya di design dengan unik agar mampu dengan mudah di ingat pembeli.
\end{abstract}

Kata Kunci: Experiential Marketing, Pengalaman Berbelanja Online, Keputusan Pembelian

\section{PENDAHULUAN}

Kondisi global dunia saat ini sedang mengalami kemerosotan. Keadaan perekonomian negara-negara berkembang mengalami ketidakseimbangan akibat kondisi ekonomi di Amerika Serikat (AS) dan Eropa. Bahkan International Monetary Fund (IMF) menyatakan kondisi ekonomi dunia akan semakin memburuk pada kuartal II, dikarenakan kondisi Eropa yang semakin memburuk.

Perekonomian dunia hanya akan tumbuh sebesar 3,5 persen pada tahun 2012, atau turun
0,1 persen dari perkiraan pada bulan April 2012. Sementara pada tahun 2013, perekonomian dunia akan tumbuh 3,9 persen, turun 0,2 persen dibanding estimasi sebelumnya. (World Economic Outlook, Oktober 2012).

Menurunnya perekonomian negara berkembang serta melemahnya negara-negara maju di Eropa, Amerika dan Jepang juga turut mempengaruhi negara disekitarnya. Permasalahan ini tidak memberikan dampak yang besar bagi Indonesia. Berita resmi terbaru 
Badan Pusat Statistik (BPS) mencatat perekonomian Indonesia triwulan III -2012 tumbuh solid 6,17 \%. Pertumbuhan yang tetap berada pada kisaran 6 persen ini melanjutkan kinerja positif triwulan I dan || 2012, dimana ekonomi tumbuh secara berturut-turut sebesar 6,3 persen dan 6,4 persen. Secara triwulanan, perekonomian pada triwulan III juga tumbuh sebesar 3,21 persen dibanding triwulan sebelumnya. Dengan kinerja pertumbuhan yang relatif stabil ini, kalangan ekonom memprediksi ekonomi Indonesia tahun 2012 akan tumbuh pada kisaran 6,2-6,3 persen. Sedikit di bawah target APBN 2012 yaitu sebesar 6,5 persen, capaian pertumbuhan pada kisaran 6,3 persen merupakan sebuah prestasi yang patut diapresiasi karena dicapai pada saat perekonomian global mengalami perlambatan.

Pertumbuhan ekonomi Indonesia yang tetap stabil di tengah perlambatan ekonomi global di dorong oleh tingginya permintaan domestik yang berasal dari konsumsi rumah tangga dan investasi. Sementara kinerja ekspor impor mengalami penurunan sebagai akibat perlambatan ekonomi di negara-negara tujuan utama ekspor. Pada triwulan III-2012, konsumsi rumah tangga tumbuh sebesar 2,3\% dibanding triwulan sebelumnya. Pengeluaran konsumsi rumah tangga ini diprediksi akan berlanjut pada triwulan IV 2012 sebagai dampak dari adanya siklus tahunan perayaan Hari Natal dan Tahun Baru yang secara historis memberikan pengaruh yang cukup signifikan terhadap peningkatan daya beli masyarakat dan pertumbuhan ekonomi.

Membaiknya persepsi pasar, perbaikan daya beli masyarakat, dan stabilnya kondisi makro ekonomi diperkirakan akan melanjutkan pertumbuhan PMTB pada triwulan IV 2012 untuk berada pada kisaran 10-11\% seperti halnya triwulan III 2012. Apabila kecenderungan perbaikan pertumbuhan investasi ini dapat dipertahankan, maka investasi akan menjadi salah satu komponen utama pendorong pertumbuhan ekonomi 2012, menggantikan kinerja ekspor yang saat ini mengalami perlambatan

Prediksi tersebut didasarkan atas perkembangan positif data-data terkait investasi, baik dari sisi kuantitas maupun kualitas. Sisi kuantitas menunjukkan kinerja penanaman modal langsung yang di-release oleh BKPM menunjukkan angka yang menggembirakan. Pada triwulan III, realisasi penanaman modal langsung mencapai Rp. 81,8 triliun, meningkat 6,4 persen dibanding triwulan II 2012, dan meningkat sebesar 25,1 persen dibandingkan triwulan I 2011. Secara kumulatif realisasi investasi pada Januari-September 2012 mencapai Rp. 229,9 triliun, meningkat 27,0 persen dari Januari-September 2011 sebesar Rp. 181,0 triliun. Artinya realisasi investasi sampai dengan September 2012 telah mencapai 81,09 persen dari target tahun 2012 sebesar Rp 283,5 triliun. Dengan situasi makro ekonomi yang relative stabil, target investasi 2012 diperkirakan akan terlewati.

Perkembangan kondisi global dan terjaganya komponen-komponen pertumbuhan menempatkan Indonesia pada posisi yang kuat dalam ekonomi global. Dalam konteks regional kawasan Asia Tenggara, pertumbuhan ekonomi Indonesia paling tinggi dibanding negara lain dalam kelompok ASEAN 5 (Indonesia, Thailand, Malaysia, Filipina, dan Vietnam) yang diprediksi hanya tumbuh 5,4 persen. Dalam kawasan Asia, pertumbuhan ekonomi Indonesia hanya di bawah China, dan bahkan mampu melampaui India. (http: //www. setkab. go. id / artikel -6342. html).

Perkembangan kondisi global Indonesia ini mengakibatkan negara-negara maju mulai tertarik untuk melakukan investasi di Indonesia. Selain alasan perumbuhan ekonomi yang baik, alasan lainnya yaitu lanskap penggunaan internet di Indonesia sedang mengalami perkembangan yang baik dibandingkan dengan penggunaan internet dinegara mereka sendiri, sehingga mengembangkan dan menginvestasikan dana yang dimiliki akan memungkinkan pertumbuhan 
ekonomi negaranya menjadi lebih baik. Adapun pertumbuhan jumlah pengguna internet di Indonesia dapat dilihat pada Gambar 1 di bawah ini.

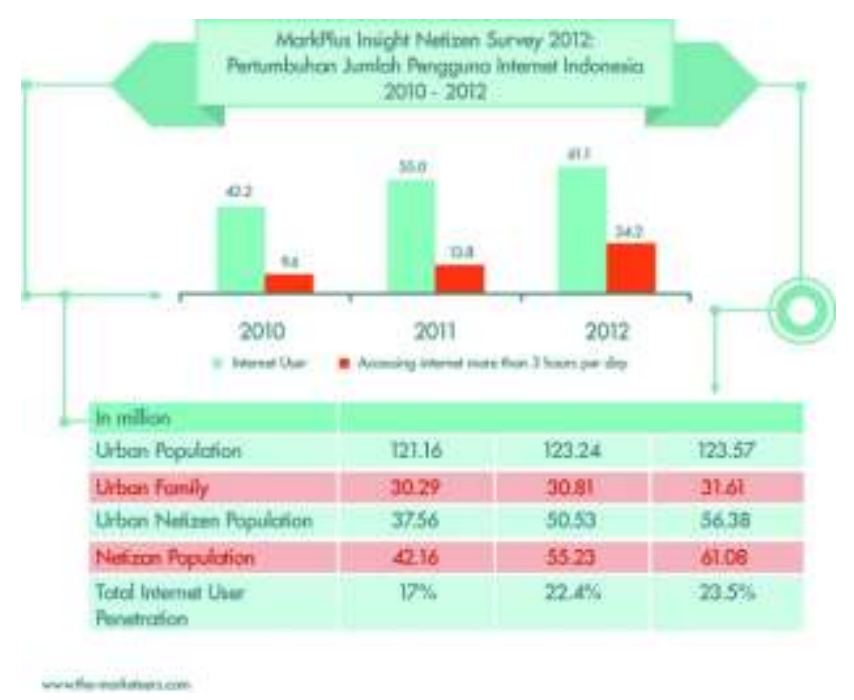

GAMBAR 1

PERTUMBUHAN PENGGUNA INTERNET DI INDONESIA 2010-2012

Gambar 1 di atas menunjukkan bahwa jumlah pengguna Internet di Indonesia yaitu sebesar 61 juta orang, atau meningkat 6 juta dari tahun sebelumnya. Penetrasi pengguna internet di Indonesia yaitu 23,5\% pada tahun 2012 dan hanya mengalami sedikit peningkatan dibandingkan dengan tahun 2011 yaitu sebesar $22,4 \%$. Meskipun pertumbuhan jumlah pengguna internet di Indonesia tidak meningkat drastis seperti tahun sebelumnya, akan tetapi terjadi peningkatan jumlah pengguna aktif yang menggunakan internet lebih dari 3 jam perhari yaitu sebesar $40 \%$ dari total pengguna internet di Indonesia, meningkat $15 \%$ dari tahun sebelumnya yang hanya $25 \%$ total pengguna internet.

Peningkatan jumlah pemakaian internet ini mengindikasikan bahwa internet sudah menjadi bagian dari kehidupan sehari-hari masyarakat Indonesia.masyarakat yang sudah mengenal internet akan selalu menggunakan internet dalam setiap aktifitasnya, Termasuk dalam aktifitas berbelanja.

Sebuah survei dan wawancara mengenai perilaku berbelanja online yang menggunakan 7373 reponden yang berasal dari 14 negara menunjukkan kecenderungan konsumen menggunakan internet untuk berbelanja online. Survei tersebut dilakukan di 25 negara dengan periode antara 5 Desember 2011 hingga 6 Februari 2012. Laporan untuk Kawasan Asia/Pasifik-Thailand, Cina, Jepang, Korea, Australia, Malaysia, Selandia Baru, Taiwan, Vietnam, Hong Kong, Indonesia, Singapura, India dan.(http: //www .marketing .co .id / blog /2012 /06 /18 / meningkatnya-pertumbuhan-belanjaonline-di-pasar-negara-berkembang/).

Hasil survei mengenai belanja online dan minat beli, menunjukkan bahwa gap tersebut terus menyempit di Kawasan Asia/Pasifik antara negara-negara maju dan negara-negara yang tengah berkembang. Thailand berada di posisi pertama sebagai negara dengan angka belanja online tertinggi (80\%). Sementara itu, pada indeks kecenderungan untuk melakukan belanja online dalam enam bulan ke depan, Indonesia mengalami peningkatan $10 \%$ dibandingkan tahun sebelumnya dengan (77\%), sedangkan Thailand dan Cina (93\%), diikuti oleh Korea (84\%), Malaysia (79\%), Vietnam menunjukkan minat berbelanja online yang cukup tinggi (87\%) yang bisa dilihat pada Gambar 2 di bawah ini:

PERCENTAGE OF PEOPLE SHOPPING ONLINE

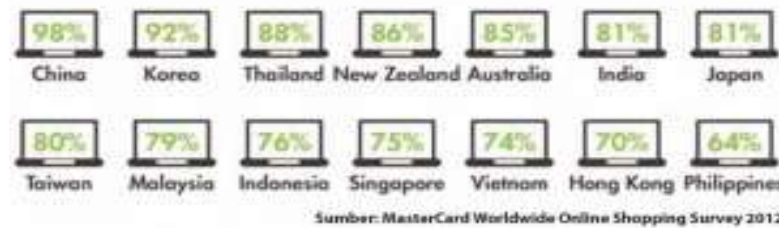

GAMBAR 2 PERSENTASE BELANJA ONLINE TAHUN 2012

Secara keseluruhan, peningkatan terbesar dalam hal berbelanja online terjadi di Thailand 
(13\%), Australia (+10\%), Indonesia (+15\%), Selandia Baru (+9), dan Filipina (+15).Sedangkan penurunan tercatat pada India (-14\%), Singapura $(-10 \%)$, dan Korea $(-17 \%)$, meskipun negaranegara yang mengalami penurunan tersebut masih memiliki minat yang cukup tinggi untuk melakukan pembelian secara online.Selain kenaikan $15 \%$ pengakses internet di Indonesia untuk keperluan berbelanja online, terlihat pula peningkatan yang substansial atas transaksi online yang terjadi dalam tiga bulan terakhir.Persentase responden yang mengakses internet untuk berbelanja online mencapai 57\%, meningkat dari $42 \%$ pada tahun sebelumnya.Sejumlah $77 \%$ responden Indonesia melakukan setidaknya satu kali pembelian online dalam tiga bulan terakhir saat survei dilakukan, naik dari angka $56 \%$ di tahun sebelumnya.Peluang seperti inilah yang coba diraih oleh maju seperti Eropa, Amerika dan Jepang untuk berinvestasi di Indonesia.

(http://www.marketing.co.id/blog/2012/06/ 18/meningkatnya-pertumbuhan-belanja-onlinedi-pasar-negara-berkembang/)

Meningkatnya jumlah pengguna internet di Indonesia diikuti dengan pertumbuhan toko online di Indonesia.Jumlah toko online terus meningkat di Indonesia sejak lima tahun lalu. Internet sudah menjadi gaya hidup masyarakat Indonesia, di tunjukkan oleh semakin banyaknya jumlah pengakses internet lewat smartphone, yang sudah mencapai lebih dari 60 juta. Internet saat ini sudah merupakan kebutuhan pokok, masyarakat dapat memperoleh berbagai macam informasi seperti berbelanja online, online banking, online marketing, online affiliate, sosialisasi online, kuliah online juga online advertising. Sebanyak $77 \%$ responden Indonesia menunjukkan kecenderungan untuk melakukan belanja online. Merupakan peluang besar sehingga banyak masyarakat yang mulai mengembangkan segala sesuatu dengan sistem online.Inilah yang mengakibatkan industri online mulai tumbuh dan berkembang dengan pesat setiap

tahunnya.

(http://www.marketing.co.id/blog/2012/06/18).

lim Fahima Jachja, praktisi informasi dan teknologi dari Virtual Consulting menyatakan bahwa selama tahun 2010, transaksi online yang terjadi di Indonesia mencapai 3,4 juta USD. Sampai Agustus 2012 jumlah tersebut meningkat hingga 4,1 juta USD. Hal ini menunjukkan pasar toko online di Indonesia lumayan besar, walaupun belum sebesar pasar toko offline yang sudah mencapai lebih dari 6 juta USD pada Agustus 2012. (http ://m .readersdigest .co.id/article/mobArticleDetail.aspx?mc=004\&sm c=001\&ar=76, 14 September 2012).

Pertumbuhan pasar toko online disertai dengan tumbuhnya situs-situs belanja online di Indonesia. Adapun 8 situs belanja online terpopuler di Indonesia bisa dilihat dalam Tabel 1 di bawah ini:

TABEL 1

8 SITUS BELANJA ONLINE POPULER DI INDONESIA MENURUT PERINGKAT ALEXA

\begin{tabular}{cl}
\hline No & \multicolumn{1}{c}{ Nama Situs } \\
\hline 1 & Rakuten Belanja Online \\
\hline 2 & Multiply \\
\hline 3 & Kaskus \\
\hline 4 & Tokobagus \\
\hline 5 & Kutukutubuku.com \\
\hline 6 & Disdus \\
\hline 7 & Dealkeren \\
\hline 8 & Tokopedia \\
\hline
\end{tabular}

Sumber:http://www.techinasia.com/popular-online-

shopping-platforms-in-indonesial

Tabel 1 di atas memperihatkan 8 situs yang paling populer di indonesia berdasarkan peringkat Alexa. Sebenarnya banyak situs jual beli yang ada di Indonesia, Tetapi situs Jual beli populer yang menjual beraneka ragam barang didominasi oleh Tokobagus dan Tokopedia.Dua situs jual beli ini memiliki kemiripan mengenai jenis produk yang dijual dan memiliki kesamaan karakteristik. Berkembangnya jual beli online ini 
sendiri dikarenakan kebutuhan dan gaya hidup konsumen dan pelaku bisnis yang menginginkan sesuatu dengan praktis. Pola pemikiran ini meningkatkan perkembangan bisnis online di Indonesia. Mereka lebih memilih menjual dan membeli barang hanya dengan duduk di depan komputer dan mereka akan mendapatkan apa yang mereka inginkan dengan mudah dan cepat.

Peningkatan jumlah penjual secara online secara tidak langsung mempengaruhi kecenderungan terhadap keputusan pembelian dari masyarakat.Konsumen semakin dimanjakan dengan banyaknya pilihan produk, penjual dan alternatif harga yang ditawarkan.Persaingan seperti ini membuat keputusan pembelian juga berubah.Begitupula yang terjadi dengan Tokobagus dan Tokopedia.Hal ini merupakan masalah serius bagi keberlangsungan situs.

Tokobagus.com targetkan transaksi penjualan hingga 300 persen dari posisi saat ini sebesar Rp 1,4 triliun per bulan pada tahun 2012. Tokobagus juga mengharapkan peningkatan sebesar $30-50 \%$ transaksi mereka.Tujuan akhirnya agar memantapkan posisinya sebagai market leader di industri jual beli online di Indonesia.Sedangkan Tokopedia terus berusaha menjadi penyedia layanan mall online terbaik dan terbesar di Indonesia.

Tokobagus dan Tokopedia harus berusaha lebih keras agar bisa mencapai target yang diinginkan, terlebih dengan banyaknya pesaing baru yang muncul yang bisa menggagalkan pencapaian tersebut. Untuk bisa mencapai targetan, Tokobagus dan Tokopedia harus memiliki strategi yang baik yang bisa mendukung situs supaya bisa mencapai tujuannya.

Tokobagus menerapkan beberapa strategi untuk mencapai tujuannya. Beberapa strategi itu antara lain meningkatkan pengawasan dan kewaspadaan terhadap terhadap transaksi yang dilakukan dengan menerapkan transaksi zero mistake. Hal ini dilakukan karena semakin banyaknya transaksi penipuan yang terjadi.Selain itu Tokobagus juga memperbaiki tampilan estalase tampilan barang agar terlihat lebih menarik.Tokobagus juga menerapkan pengawasan terhadap iklan yang dipasang serta menetapkan standar mutu bagi setiap transaksi yang berlangsung.

Tokopedia memiliki strategi yang berbeda dalam mencapai tujuannya. Tokopedia memiliki jenis rekening escrow yang memastikan bahwa setiap transaksi di Tokopedia adalah aman dan penipuan tidak akan terjadi. Ini bisa meningkatkan kenyamanan dalam melakukan belanja online. Selain itu Tokopedia menambahkan beberapa kebijakan baru dalam ketentuan upload produk yaitu penutupan permanen kategori Adult. Ini menempatkan Tokopedia sebagai Mall online untuk segala umur. Tokopedia juga melakukan kampanye anti CD/DVD bajakan, strategi lain yang akan diterapkan pada akhir tahun 2012 Tokopedia menjanjikan akan meluncurkan mobile-site yang lebih baik dibanding mobile-site saat ini. Akhir tahun ini, situs tokopedia akan lebih mudah diakses lewat Blackberry, Android maupun iPhone. Hal ini bertujuan agar transaksi bisa semakin mudah dan menyenangkan.

Untuk bisa memberikan pengalaman yang menyenangkan, Tokobagus dan Tokopedia harus memiliki strategi yang berbeda dibandingkan dengan situs lain. Pembeli akan mudah mengingat apabila situs bisa memberikan pengalaman menyenangkan. Pengalaman menyenangkan bisa diciptakan melalui penerapan experiential marketing.

Experiential marketing diterapkan di Tokobagus dan Tokopedia.Mereka berusaha untuk memasuki tempat khusus dalam konsumen yang ada hubungannya dengan pikiran inspiratif tentang kenyamanan dan kesenangan, serta menginspirasikam kepraktisan. Pemasar harus memiliki pemahaman yang kuat pada pola pikir dari target audiens yang ingin dituju, dan dengan memahami apa yang konsumen cenderung pikir dan rasakan, maka akan memungkinan untuk mendapatkan ide 
tentang bagaimana mengarahkan pelanggan ke arah yang akan berhubungan dengan produk, dan menarik individu untuk bertindak atas dorongan untuk membeli. Adapun tujuan dari experiential marketing adalah untuk membangun hubungan sedemikian rupa sehingga konsumen merespon penawaran produk didasarkan pada tingkat respons emosional dan rasional.

Implementasi experiential marketing di Tokobagus bisa dilihat dari penggunaan unsurunsur visual yang kuat yang ditunjukkan dalam tampilan design, penataan produk yang menarik, pemilihan warna situs, juga penetapan warna dan bentuk logo dari Tokobagus itu sendiri. Selain itu Tokobagus juga menyediakan beraneka ragam produk supaya pembeli mendapatkan sensasi menyenangkan ketika berbelanja. Dengan penerapan hal ini diharapkan akan bisa menciptakan customer experinece, hubungan antara produk dan konsumen menjadi kokoh yang dapat membantu untuk membuat barang atau jasa yang lebih diingat dalam setiap kesempatan.

Penerapan experiential marketing di Tokopedia terlihat dari pemilihan warna dan logo.Logo Tokopedia yaitu gambar keranjang belanja dan tulisan Tokopedia dengan warna hijau. Pemilihan logo dan warna ini bertujuan agar dapat lebih masuk ke dalamexperiential marketing. Tampilan penataan produk yang teratur, pengelompokkan kategori yang sesuai, juga kemudahan dalam transaksi penjualan adalah hal yang ditonjolkan dari Tokopedia. Penerapan experiential marketing pada akhirnya diharapkan akan mampu menciptakan pengalaman yang mengesankan, menimbulkan memori yang positif sehingga pembeli akan mudah mengingat Tokopedia sebagai salah satu situs belanja yang menyenangkan.

Selain hal diatas, Tokobagus dan Tokopedia juga memberikan experience yang berbeda dengan situs lainnya. Untuk menciptakan experience Tokopedia dan Tokobagus mengkomunikasikan dan menggambarkan dengan baik tentang produk yang mereka jual.
Untuk produk ponsel misalnya, mereka menuliskan spesifikasi dan fitur jelas produknya.Kelebihan dan kekurangan serta menyertakan video mengenai ponsel tersebut. Pada produk parfum mereka menyertakan komposisi yang terkandung di dalamnya, aroma dan jenis wangi yang akan muncul apabila digunakan. Hal seperti inilah yang membuat pembeli merasakan experience, dan seolah merasakan atau memegang langsung produk yang mereka lihat tersebut. Penciptaan experiential marketing pada situs online ini diharapkan akan mampu menciptakan nilai pengalaman pelanggan. Nilai pengalaman pelanggan diciptakan supaya situs lebih mudah diingat dan menciptakan sensasi yang berbeda yang dirasakan oleh pelanggan.Experiential marketing memegang peranan untuk menciptakan pengalaman pelanggan.Dengan menarik bagi semua indera, dan membuat koneksi dengan cepat dan mulus, pendekatan atas tugas pemasaran ini dapat memastikan bahwa bisnis masih dapat menarik dan memenuhi kebutuhan dan keinginan konsumen.

Memberikan pengalamanpelanggan yang baikbaik secara online merupakan suatu keharusan. Karenasebuahpenelitianyangdirilis olehMarketTools pada tahun 2011 menunjukkan,60 persenkonsumen mengatakan bahwa merekalebih seringberbelanjadi websitetertentu karenapengalaman (experience) belanjayang menyenangkan. Pengalaman (Experience) adalah peristiwa pribadi yang terjadi sebagai jawaban atas beberapa rangsangan. Pengalaman atau experience melibatkan seluruh dalam setiap peristiwa kehidupan. Dengan kata lain, sebagai perusahaan harus menata lingkungan yang benar untuk pelanggan dan apa sebenarnya yang diinginkan pelanggan. Pengalaman atau experience pada umumnya bukan dihasilkan atas diri sendiri tapi bersifat membujuk pada atau secara psikologi pengalaman adalah sesuatu hal yang terjadi tanpa unsur kesengajaan (Schmitt 1999:60). 
Adapun penciptaan experience tersebut bisa mengarah pada indera pada dimensi sense yaitu meningkatkan nilai konsumen melalui penglihatan, suara, sentuhan. Pengalaman feel yang mengarahkan perasaan dari dalam pada konsumen dan emosi, nilai konsumen diciptakan melalui pengalaman efektif yang diarahkan pada perasaan positif dihubungkan dengan merek (yaitu untuk mereka yang tidak terlibat, merek grosir atau servis atau produk industri) untuk emosi yang kuat terhadap kenikmatan dan kebanggaan. Pengalaman think dalam intelektual: menciptakan nilai konsumen, menciptakan pengalaman act untuk perilaku dan gaya hidup, menciptakan nilai yang memprlihatkan suatu gaya hidup alternative atau cara alternatif dalam menjalankan bisnis.Pengalaman relate yang memuat pengalaman sosial. Sekaligus menciptakan nilai untuk konsumen dengan memberikan identitas sosial. Penciptaan nilai pengalaman pelanggan melalui experiential marketing ini pada akhirnya diharapkan akan mampu mempengaruhi keputusan pembelian konsumen.

$$
\text { Mengingat pentingnya keputusan }
$$
pembeliandalam pelaksanaan bisnis online serta penerapan experientiel marketing online yang mampu menciptakan nilai pengalaman pelanggan, maka peneliti merasa perlu untuk melakukan penelitian dengan judul "Analisis Nilai

Pengalaman Berbelanja Online Melalui Experiential Marketing (Survei pada Pembeli di Situs Tokobagus.com dan Tokpoedia.com)".

\section{KERANGKA PEMIKIRAN}

Strategi pemasaran berkembang dengan cepat, mulai dari strategi pemasaran jasa hingga pemasaran experiential, menurut Hermawan Kartajaya (SWA2001:44) saat ini ada lima tingkatan pemasaran yang terus berkembang di dunia bisnis.

Pertama, pemasaran komoditas, pada tahap ini tidak ada pembeda antara produk yang satu dengan produk yang lainnya, hargapun tidak bisa ditentukan sendiri karena bergantung pada suplai dan permintaan.Kedua, goods marketing, pemasaran pada tahap ini sudah memperhatikan diferensiasi antar produk dan sudah bisa menentukan harga sendiri. Ketigaservice marketing, dimana konsumen telah membeli produk/jasa dalam satu paket lain seperti layanan sebelum dan sesudah penjualan, pada tahap ini pula konsumen sudah bisa mempertimbangkan tingkat kepuasan mereka. Keempat, experiential marketing, yaitu tahapan pemasaran di lingkungan pasar yang sudah paham dengan service marketing. Pada tahapan ini dilakukan pendekatan dengan menghadirkan pengalaman holistik melalui penggunaan seluruh panca indera. Terakhir adalah transformation marketing, pada tahap ini pemasar tidak hanya menciptakan memori jangka panjang, tetapi bisa melakukan perubahan transformasi secara lebih permanen.

Kondisi sekarang pemasar dituntut menjalankan strategi pemasaran experiential, dimana pasar tidak lagi melakukan permintaan akan barang dan jasa yang berkualitas, tetapi juga manfaat emosional berupa pengalaman tak terlupakan (memorable experience) yang mempererat hubungan konsumen dengan produsen melalui produk yang ditawarkan.

\section{Gagasan pemasaran experiential} (experiential marketing) tersebut dikenalkan oleh Bernd H.Schmitt pada tahun 1999. Menurut Schmitt (1999:3), ditengah era revolusi pemasaran ini strategi experiential marketing akan menggeser pendekatan tradisional yang menekankan pada fitur dan benefit produk, serta memandang konsumen sebagai sosok yang rasional. Menurutnya pendekatan tradisional tanpa melibatkan unsur emosi dan pengalaman merupakan strategi yang rentan dari peniruan atau penyerangan produk serupa oleh pesaing.

Pendekatan experiential marketing dibentuk guna melengkapi pendekatan tradisional dengan menghadirkan pengalaman-pengalaman yang 
unik, positif dan mengesankan yang membentuk memorable experience bagi konsumen. Pengalaman tak terlupakan tersebut adalah nilai berupa emotional benefit (manfaat emosional) yang ditawarkan sesuai dengan kebutuhan konsumen dan menjadi keunggulan perusahaan yang sulit ditiru oleh pesaing.

Schmitt (1999:60) menjelaskan kerangka kerja konseptualdalam mengelola akumulasi pengalaman pelanggan (experiental marketing) bagi suatu perusahaan. Fokus kerangka kerja (frame work) tersebut dibagi menjadi dua konsep yaitu strategic experiential modules (SMEs) yang merupakan pondasi experiential marketing dan experiences providers (ExPros) sebagai alat taktis untuk mengimplementasi experiential marketing.

Experiental modules

(SMEs) mendeskripsikan lima tipe tahapan pengalaman yang menjadi bentuk dasar experiential marketing frame work, kelima tipe tersebut adalah sense, feel, think, act dan relate.

Sense Marketing adalah Bagian dari experiential marketing yang di laksanakan untuk mengikat panca indera konsumen dan memberikan kesan keindahan, kesenangan, kecantikan dan kepuasan melalui stimulasi sensori. Adapun sense ini diciptakan melalui Pengalamanyang mengikat panca indera melalui tampilan logo, design, (Pemilihan unsur warna logo,tampilan di situs jual beli, Pemilihan desain situs jual beli), Pelayanan (Keramahan pelayanan, Kesigapan pelayanan, Kemudahan dalam bertransaksi).

Feel adalah Kinerja produk/jasa dalam menyentuh perasaan/emosi dengan sasaran membangkitkan pengalaman afektif. Hal ini dilakukan melalui Pengalaman yang mengikat panca indera melalui: (Pemilihan unsur warna dan logo di situs jual beli, Pemilihan desain dan alternatif produk, Pelayanan (Keramahan pelayanan, Kesigapan Kemudahan dalam bertransaksi.

Dengan berpikir (think) dapat merangsang kemampuan intelektual dan kreativitas seseorang. Sebagai contoh penerapan pada situs jual beli, yaitu dengan dipasangnya logo dan identitas perusahaan pada tampilan situs, sehingga mampu menimbulkan pemikiran positif dari pembeli, serta membuat pembeli bisa membedakan antara situs yang satu dengan situs lainnya.

Act berkaitan dengan perilaku yang nyata dan gaya hidup seseorang. Hal ini berhubungan dengan bagaimana membuat orang berbuat sesuatu dan mengekspresikan gaya hidupnya. Pada bisnis online, act ditunjukan dengan bergabungnya seseorang pada situs atau komunitas online, serta ikut sertanya seseorang pada event yang diadakan oleh situs jual beli. Hal tersebut menunjukan gaya hidup seseorang. Jadi 'Act' di sini meliputi perilaku yang nyata atau gaya hidup yang lebih luas.

Relate berkaitan dengan budaya seseorang dan kelompok referensinya yang dapat menciptakan identitas sosial. Seorang pemasar harus mampu menciptakan identitas sosial (generasi, kebangsaan, etnis) bagi pelanggannya dengan produk atau jasa yang ditawarkan. Pada bisnis online, relate dapat ditunjukkan bergabungnya seseorang dalam komunitas bisnis tertentu, adanya komunikasi antara orang dengan anggota yang lainnya, adanya kerjasama yang terjalin antara anggota grup yang satu dengan yang lainnya.

Experiential providers (ExPros) menjelaskan bagaimana SEMs dapat dibentuk atau disebut juga dengan contact point antara produsen dan konsumen dimana ExPros ini adalah medium yang mampu mengoptimalkan rangsangan SEMs. Media yang digunakan dapat berupa communications, visual/verbal identity, product presence, co-branding, spatial environment, electronic media dan people.

Keberhasilan experiential marketing melaui strategic experiential modules yang diwujudkan dengan Experiential Providers di atas tergantung pada usaha produsen dalam mengemas produk/jasanya secara emosional. Menurut Rolf Jensen (SWA, 2001:53) kecenderungan para 
pemasar mengemas emosi secara komersial telah mendorong transisi ke dream society, yaitu suatu bentuk masyarakat yang membentuk emotional market (pasar dimana konsumen tidak semata membeli produk, melainkan gaya hidup, petualangan, cinta dan persahabatan, kedamaian serta kepercayaan). Sementara itu, menurut Scott Robinette dan Claire Brand (2006:12) dalam emotion marketing terdapat rantai nilai yang memandang konsumen tidak hanya dari segi rasional tetapi juga emosional, nilai-nilai tersebut dikenal dengan teori bintang nilai (Value Star) yang terdiri dari Money dan Product sebagai nilai rasional serta Equity, Experience dan Energy sebagai nilai emosional. Rational Value menjelaskan nilai yang diterima konsumen pada setiap penggunaan produk dan jasa serta membandingkannya dengan nilai uang (rasional), sedangkan emotional value menjelaskan nilai yang diterima konsumen dari sudut ekuitas, pengalaman dan energi.

Nilai ekuitas menurut Scott (2006:44) adalah segala sesuatu yang diterima konsumen atas dasar kepercayaan yang dibangun perusahaan melalui identitas dan image mereknya. Ketika perusahaan memenuhi janji atas brand promises yang dibuatnya, maka perusahaan telah membentuk identitas dan kepribadian merek yang memberikan aspirasi positif bagi konsumen.

Nilai lain yang dibentuk melalui emosional adalah pengalaman. Scott (2006:64) menegaskan bahwa pengalaman adalah "the collection of points at wich companies and consumers exchange sensory stimuli, information, and emotion." Menurutnya pengalaman adalah sekumpulan peristiwa ketika perusahaan melakukan transaksi, pertukaran informasi, dan emosi yang terjadi antara konsumen dengan produsen dimana konsumen memperolehnya melalui:
a. Pengalaman dengan produk
b. Pengalaman dengan lingkungan
c. Pengalaman komunikasi
d. Pengalaman dalam pelayanan konsumen

e. Pengalaman dalam kegiatan (event).

Kumpulan pengalaman di atas merupakan dasar pembentukan kepercayaan yang dibangun perusahaan terhadap konsumennya.Perilaku pembelian seseorang bisa dipengaruhi oleh berbagai faktor, baik faktor internal maupun faktor eksternal. Faktor internal merupakan faktor yang mempengaruhi perilaku pembelian dan berasal dari dalam diri seseorang, sedangkan faktor eksternal merupakan faktor yang mempengaruhi faktor pembelian dan berasal dari luar. Kedua faktor ini, yakni faktor internal dan faktor eksternal mempunyai pengaruh yang cukup signifikan dalam mempengaruhi keputusan pembelian konsumen. Penciptaan pengalaman adalah upaya untuk mempengaruhi pembelian yang dipengaruhi oleh faktor eksternal.

Menurut Kotler dan Armstrong (2012:135150) faktor-faktor yang mempengaruhi keputusan pembelian terdiri dari faktor budaya, sosial, pribadi, dan psikologi. Adapun faktor psikologi terdiri dari Motivasi, persepsi, personality, sikap dan emosi.

a. Motivation, Beberapa kebutuhan bersifat biogenik; kebutuhan itu timbul dari keadaan tekanan psikologis seperti rasa lapar, rasa haus atau rasa tidak nyaman. Kebutuhan lain bersifat psikogenik; kebutuhan yang timbul dari keadaan tekanan psikologis seperti kebutuhan akan pengakuan, penghargaan, atau rasa memiliki. Kebutuha menjadi motif ketika kebutuhan itu meningkat sampai tingkat intensitas yang cukup sehingga mendorong kita bertindak.

b. Perception, Orang yang termotivasi siap bertindak, bagaimana ia bertindak dipengaruhi oleh pandangan tentang situasi. Persepsi adalah proses dimana kita memilih, mengatur, menerjemahkan masukan informasi untuk menciptakan gambaran dunia yang berarti.

c. Learning, Pembelajaran mendorong perubahan dalam perilaku kita yang timbul 
dari pengalaman. Sebagian besar perilaku manusia dipelajari, meskipun sebagian pembelajaran itu tidak disengaja.

d. Belifes and attitude, Beliefes dan sikap, keyakinan adalah sebuah pemikiran deskriptif bahwa seseorang memiliki sesuatu. Keyakinan mungkin didasarkan pada pengetahuan nyata, pendapat, atau iman dan mungkin atau tidak mungkin membawa muatan emosional. Sikap menggambarkan evaluasi seseorang yang relatif konsisten, perasaan, dan kecenderungan ke arah suatu obyek atauide.

Selanjutnya paradigma penelitian ini akandijelaskandalam gambar pada halaman selanjutnya:

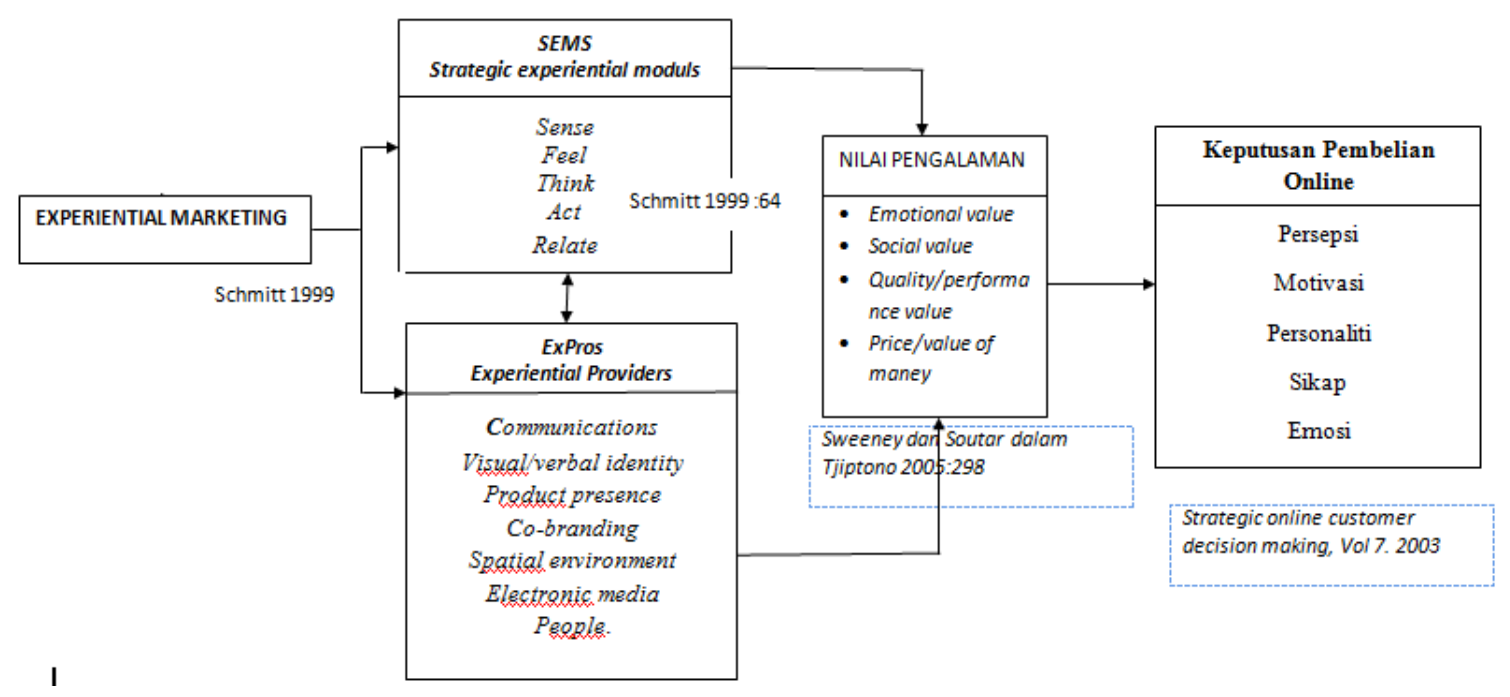

\section{METODE PENELITIAN}

Penelitian ini menggunakan pendekatan manajemen pemasaran khususnya mengenai Penciptaan Nilai pengalaman berbelanja online melalui Experiential Marketing Online serta Pengaruhnya Terhadap Keputusan Pembelian di Situs Jual Beli Online. Adapun yang menjadi objek penelitian sebagai variabel bebas (independent variable) adalah $(\mathrm{X})$ yang meliputisense, feel, Think, Act dan Relate, Nilai pengalaman berbelanja online $(\mathrm{Y})$ yang meliputiEmotional value, Social value, Quality/performance value, dan Price/value of maney. Experiential Marketing.Variabel terikat (dependent variable)
adalahProsesKeputusan Pembelian (Z) yang terdiri dari persepsi, motivasi, personaliti, sikap dan emosi.

Penelitian ini dilakukan terhadap pembeli di situs jual beli yaitu pada Tokobagus.com dan Tokopedia.com. Berdasarkan objek penelitian, maka akan dianalisis mengenai Penciptaan Nilai pengalaman berbelanja online melalui Experiential Marketing Online serta Pengaruhnya Terhadap Keputusan Pembelian di Situs Jual Beli Online.

Penelitian ini dilakukan dalam kurun waktu kurang dari satu tahun, maka pendekatan yang digunakan menurut Husein Umar (2008:45) cross sectional method, yaitu metode penelitian dengan cara mempelajari objek dalam kurun 
waktu tertentu (tidak berkesinambungan dalam jangka waktu panjang)dalam penelitian yang menggunakan metode ini, informasi dari sebagian populasi dikumpulkan langsung di tempat kejadian secara empirik dengan tujuan untuk mengetahui pendapat dari sebagian populasi terhadap objek yang sedang diteliti di lapangan.

yang menjadi populasi dalam penelitian ini adalahMember situs jual beli Tokobagus.com dan Tokopedia.com. Pada Tabel 2 berikut ini merupakan rincian jumlah member Tokobagus.com dan Tokopedia.com tahun 2012

TABEL 2

JUMLAH MEMBER SITUS TOKOBAGUS.COM DAN TOKOPEDIA.COM TAHUN 2012

\begin{tabular}{lr}
\hline \multicolumn{1}{c}{ Nama Situs } & \multicolumn{1}{c}{ Jumlah Member } \\
\hline Tokobagus.com & 3.294 .071 \\
\hline Tokopedia.com & 56538 \\
\hline
\end{tabular}

Sumber: Modifikasi dari internet 2012

\section{HASIL DAN PEMBAHASAN}

Secara keseluruhan, gambaran experiential marketingdi situs jual beli Tokobagus dan Tokopedia dilakukan melalui pendekatanlima dimensi, yaitu sense, feel, think, act dan relate.Masing-masing dimensi memberikan gambaran produk/jasa yang ditawarkan, mulai dari tampilan situs, variasi produk yang ditawarkan pelayanan, kemudahan dalam bertransaksi dalam melakukan melayani konsumen.

Sense experience adalah usaha penciptaan pengalaman dengan menggunakan unsur panca indra. Sesuai dengan pendapat Schmitt (1999:63) bahwa sense experience akan memotivasi konsumen untuk membeli produk, dan penerapan sense experience yang baik akan menciptakan kepuasan yang pada akhirnya akan mendorong terciptanya loyalitas. Skor tertinggi dalam sense didapatkan oleh Tokobagus dalam item pertanyaan 6 yaitu mengenai pelayanan di Tokobagus yang menunjukkan skor 3,76 yang berarti memiliki kinerja pelayanan yang sangat baik. Sedangkan skor terendah juga diperoleh dari Tokobagus pada item pertanyaan 1 mengenai design dan tampilan situs yang memperoleh skor 2,85 berada di bawah standar yang artinya memiliki kinerja yang belum baik, dan harus di perbaiki.

Perolehan tertinggi dari dimensi sense di Tokopedia berada pada item pertanyaan ke 7 yaitu mengenai kesan kinerja situs. Rata-rata perolehan skor pada item pertanyaan tersebut yaitu 3,73 yang menunjukkan hasil perolehan kinerja Tokopedia sangat baik. Sedangkan skor terendah pada item pertanyaan ke 1 yaitu mengenai design dan tampilan situs, hanya memperoleh skor 3,51 yang berarti design dan tampilan situs Tokopedia masih harus diperbaiki supaya menjadi lebih menarik. Sesuai dengan pendapat Schmitt(1999:63) yaitu "sense didefinisikan sebagai usaha penciptaan pengalaman yang berkaitan dengan panca indra melalui penglihatan, suara, sentuhan dan bau. Dimana bisa digunakan untuk memotivasi konsumen untuk membeli produk tersebut dan menyampaikan value kepada konsumen". Semakin besar sense bisa diterapkan, maka value yang bisa diraskan konsumen akan semakin besar juga.

Skor tertinggi yaitu pada item pertanyaan ke 4 dan ke 7 yaitu mengenai kesesuaian pengelompokkan produk dan perasaan saat meninggalkan situs yaitu memperoleh skor 3,72 yang melewati skor rata-rata. Hal ini menunjukkan kinerja Tokobagus mengenai kesesuaian pengelompokan produk sudah sangat baik sehingga pembeli merasa puas saat meninggalkan situs.Skor terendah dari tanggapan pembelimengenaifeel dalam program experiental marketing di Tokobagus yaitu item pertanyaan pertama mengenai perasaan saat melihat design dan tampilan situs yang memperoleh skor 3,33 berada di bawah standar yaitu 3,62. Hal ini 
berarti tampilan situs Tokobagus masih harus banyak di perbaiki supaya bisa menimbulkan feel positif.

Perolehan skor tertinggi Tokopedia adalah pada item pertanyaan ke 4 yaitu mengenai kesesuaian pengelompokkan produk yaitu memperoleh skor 3,78 yang berarti pengelompokkan produk di Tokopedia sangat baik sehingga pembeli suka melakukan transaksi. Perolehan skor terendah yaitu pada item pertanyaan pertama mengenai perasaan daat melihat design dan tampilan situs. Perolehan yang di bawah standar ini berarti Tokobagus harus berusaha memperbaiki tampilan dan design agar pembeli bisa merasa nyaman dan senang sehingga bisa menimbulkan feel positif.

Perolehan skor tertinggi untuk Think di Tokopedia yaitu pada item pertanyaan ke 4 dan ke 7 yaitu mengenai promosi yang dilakukan serta kesan saat meninggalkan situs. Promosi yang diterapkan di Tokopedia dinilai sangat baik, hal ini bisa dilihat dari media promosi yang digunakan untuk memperkenalkan Tokopedia di media elektronik seperti di media internet dan juga bioskop. Selain itu kesan saat meninggalkan situs dirasakan positif oleh pembeli. Hal ini harus di tingkatkan agar pembeli bisa terus melakukan transaksi kembali. Skor terendah diperoleh pada item pemikiran saat melihat identitas perusahaan. Memperoleh skor 3,5 yang menunjukkan identitas perusahaan belum bisa menimbulkan pemikiran positif di benak pembeli.

Perolehan skor tertinggi yang diperoleh Tokobagus yaitu pada item pertanyaan pertama tentang mencari informasi mengenai produk di Tokobagus. Hal ini menunjukkan bahwa Tokobagus bisa membuat pembeli untuk mencari informasi di situs sewaktu mereka membutuhkan produk tertentu. Berarti Tokobagus sudah bisa memberikan kesan di benak pembeli untuk segera mengingat situsnya ketika mereka membutuhkan barang. Sedangkan item terendah diperoleh pada pertanyaan ke 4 yaitu pembeli jarang mengikuti event yang diadakan. Hal ini di karenakan pembeli mengganggap event yang diadakan tersebut kurang menarik, sehingga tidak menimbulkan kesan positif.

Sedangkan skor tertinggi dari tanggapan pembeliterhadap act dalam program experiential marketing Tokopedia adalah pada item pertanyaan ke 2 yaitu pembeli akan mencari produk di Tokopedia seandainya mereka ingin membeli produk. Hal ini berarti Tokopedia memberikan banyak experience sehingga bisa membuat pembeli langsung mengakses situs Tokopedia sewaktu mereka ingin membeli produk. Perolehan skor terendah yaitu pada item pertanyaan nomer 4 yaitu mengenai event yang jarang diikuti oleh pembeli. Sama seperti Tokobagus, Tokopedia harus berusaha lebih kreatif dan berusaha mengikuti trend yang sedang berkembang dan menyesuaikannya dengan event yang akan dilaksanakan agar pembelibisa semakin banyak yang aktif berpartisipasi mengikuti event yang diadakan. Sesuai dengan pendapat Schmitt (1999:74) yang mengemukakan bahwa "act experience yang berupa gaya hidup dapat diterapkan dengan menggunakan trend yang sedang berlangsung atau mendorong terciptanya trend budaya baru".

skor terendah dari tanggapan member terhadap Relate dalam program experiental marketing di Tokobagus yaitu item pertanyaan ke 2 dan ke 4 yaitu mengenai keinginan untuk menjadi member dan rekomendasi mengenai situs kepada orang lain. Skor tertinggi diperoleh pada item pertanyaan ke 1 yaitu keinginan untuk menjadi pelanggan di situs. Hal ini menunjukkan penerapan Relate di Tokobagus sudah berjalan dengan baik

Perolehan skor di Tokopedia terendah diperoleh oleh item pertanyaan nomer 3 yaitu keinginan untuk bergabung di komunitas situs jual beli. Perolehan tertinggi di peroleh item pertanyaan ke 2 yaitu keinginan untuk menjadi member di Tokopedia. Hal ini mengindikasikan bahwa pembeli sangat menyukai transaksi di Tokopedia sehingga mereka ingin menjadi 
member, akan tetapi mereka tidak ingin bergabung di komunitas karena mereka belum merasa komunitas yang diciptakan Tokopedia bisa mencerminkan gaya hidup mereka.

\section{KESIMPULAN}

Berdasarkan hasil penelitian yang dilakukan oleh peneliti melalui analisis deskriptif dan verifikatif dengan menggunakan Partial least square, maka berdasarkan penelitian tersebut dapat diambil kesimpulan sebagai berikut:

1. Experiential marketing pada Tokobagus dan Tokopedia menunjukkan bahwa pada dimensi sense ternyata alternatif pilihan produk paling menyentuh panca indera, di mana Tokobagus dan Tokopedia menawarkan berbagai jenis kategori produk yang dikelompokkan menurut jenisnya, sehingga dirasakan yang paling menyentuh panca indera pelanggan. Pada dimensi feel, yang paling menggugah perasaan member adalah tata letak dan tampilan produk. Tata letak yang sistematis dan tampilan produk yang menarik membuat pembelimerasa senang dan nyaman melakukan transaksi di Tokobagus dan Tokopedia. Penilaian tentang promosi situs jual beli dinilai paling tinggi dalam dimensi think, di promosi yang di lakukan melalui iklan di website lain, bahkan Tokopedia menimbulkan pemikiran positif bagi yang melihatnya.melakukan promosi di bioskop atau Tokobagus melakukan promosi melalui media televisi dinilai paling baik sehingga pembeli memberikan penilaian positif. Sedangkan pada dimensi act menyatakan bahwa pembeli akan mencari di situs jual beli Tokobagus dan Tokopedia apabila mereka membutuhkan produk. Kemudahan yang ditawarkan, banyaknya variasi produk, serta tampilan dan tata letak membuat pembeli akan cenderung mencari di situs Tokobagus dan Tokopedia apabila mereka membutuhkan produk tertentu.

2. Pada penciptaan nilai pengalaman pelanggan, yang memperoleh skor terbesar adalah pembeli merasa puas dengan produk yang dibelinya. Adanya kepuasan terhadap produk yang di eli menimbulkan keinginan untuk melakukan pembelian kembali.

3. Keputusan Pembelian di Tokobagus dan Tokopedia Tinggi.Pada keputusan pembelian nilai tertinggi di peroleh pada item pertanyaan membeli produk karena rekan juga membelinya. Ini menunjukkan keputusan pembelian tidak hanya dipengaruhi oleh faktor dari luar akan tetapi faktor dari dalam juga sangat berpengaruh terhadap keputusan pembelian.

4. Experiential marketing berpengaruh terhadap nilai pengalaman pelanggan. konstrakthink, act dan relate berpengaruh secara signifikan terhadap nilai pengalaman pelanggan, sedangkan sense dan feel tidak berpengaruh secara signifikan terhadap nilai pengalaman pelanggan.

5. Experiential marketing berpengaruh terhadap nilai pengalaman pelanggan dan berdampak pada keputusan pembelian.

\section{REKOMENDASI}

Berdasarkan hasil penelitian, maka penulis merekomendasikan beberapa hal mengenai implementasi experiential marketing agar dapat menciptakan nilai pengalaman pelanggan yang pada akhirnya akan berdampak pada keputusan pembelianyaitu:

1. Memperbaiki design dan tampilan situs supaya lebih menarik perhatian, sehingga bisa merangsang emosi seseorang dan menimbulkan keinginan untuk membeli produk. Tampilan sebaiknya di design dengan unik agar mampu dengan mudah di ingat pembeli. 
2. Berusaha membuat event yang lebih variatif dan menarik, agar pembeli yang ingin turut berpartisipasi dalam kegiatan yang di adakan Tokopedia dan Tokobagus.

3. Menambah jenis produk yang disesuaikan dengan perkembangan kebutuhan saat ini, yang ditunjang dengan sistem pembayaran yang lebih baik. Hal ini perlu di lakukan karena sebagian orang masih merasa kurang yakin untuk melakukan transaksi online karena alasan keamanan.

4. Menciptakan komunitas yang berkelas sehingga orang yang bergabung di dalemnya bisa merasa bangga dan meningkatkan prestisenya. Komunitas juga harus di sesuaikan dengan gaya hidup. Karena sebagian besar orang menggunakan komunitas untuk menunjukkan kelas sosialnya.

5. Perlu melakukan pembatasan dan menetapkan standar khusus dalam berjualan. Juga menetapkan barang-barang yang bisa diperjual belikan sehingga aktifitas jual beli menjadi semakin menyenangkan dan situs jual beli tidak dirugikan oleh oknum yang menjual barang-barang yang merugikan kesehatan atau seharusnya tidak pantas diperjual belikan.

6. Perlu peningkatan program experiental marketing secara keseluruhan dengan lebih baik lagi agar bisa menimbulkan nilai pengalaman pelanggan yang lebih tinggi, agar keputusan pembelian bisa meningkat. Hal ini menunjukkan bahwa pihak Tokobagus dan Tokopediaharus dapat memberikan pengalaman yang lebih baik kepada pengunjung melalui peningkatan pelayanan serta menambah berbagai jenis produk yang ditawarkan. Selain itu peningkatan aspek lainnya juga perlu dilakukan untuk memberikan sesuatu yang berbeda dan lebih baik kepada para pengunjung sehingga suatu pengalaman yang tidak terlupakan pun tercipta di pikiran pelanggan.

\section{DAFTAR PUSTAKA}

Diana LaSalle dan Terry A.Britton, 2008, Turning Ordinary Products Into Extraordinary Experience, Boston: Harvard Business School Press

Fandy Tjiptono, (2008). Strategi Pemasaran, Yogyakarta: Penerbit Andi

Hermawan, Asep, (2006), Penelitian Bisnis Paradigma Kualitatif, Jakarta: PT Gramedia Widia Sarana Indonesia.

Husein Umar, 2008. Metode Penelitian untuk Skripsi dan Tesis Bisnis Edisi 2. Jakarta: PT Raja Grafindo Persada.

H, Schmitt, Bernd, (1999), Experiential Marketing: How to get customer to sense, feel, think, act and relate to your Company and Brand, The free Press : New York

H, Schmitt, Bernd, at all, (2004), There's No Business That Not Show Business: Marketing In An Experiences Culture, Prentice Hall: New York

Kertajaya, Hermawan. (2003), Marketing Plus: Siasat Memenangkan Persaingan Global. Jakarta: penerbit PT. Gramedia pustaka utama.

Kartajaya, Hermawan, et.al, (2007). MarkPlus on Strategy: 12 Tahun perjalanan MarkPlus\&Co Membangun Strategi Perusahaan. Jakarta: PT Gramedia Pustaka Utama.

Pine, B. Joseph II, and James H. Gilmore, 1999, Welcome to The Experience

Economic. Harvard Business Review, 76 (July August) 97-105. 
Ratih Hurriyati, 2005. Manajemen Pemasaran Jasa dan Loyalitas, Alfabeta, Bandung

Scott, R. William. 2006.Financial Accounting Theory 4th Edition. Prentice-Hall, NewJersey

Sheth, J.N \& Mittal, Banwari (2004) Customer Behavior : a manajerial perspektif. Amerika: Thompson Learning

Sugiyono, (2011), Metode Penelitian Bisnis, Alfabeta : Bandung.

Smilansky, Shaz, (2009), Experiential Marketing: A Practical guide to interactive brand experiences, Kogan Page: London

Suwarman U.,et al (2010). Pemasaran Strategik: Perspektif Value-Based Marketing \& Pengukuran Kinerja. Bogor: IPB Press

Zeithaml, Valarie A. dan Bitner, Mary Jo., (2006), Service Marketing $2^{\text {nd }}$ edition: Integrating Customer Focus., New York: McGraw Hill Inc.

\section{Penelitian Terdahulu}

Christianingrum.Pengaruh penerapan experiential marketing terhadap loyalitas member salon humaira. 2010

Dini Rismalati. Pengaruh sense dan feel pada experiental marketing terhadap brand identity serta implikasinya pada costumer brand relationship program acara reality show AFI. 2005

Lili Adi Wibowo. Pengaruh experiential marketing dan emotional value terhadap loyalitas pelanggan cafe dan resto di kawasan cihideung, Lembang, Bandung. Jurnal IImiah Agustus vol 4 No 8, tahun 2004

Simarmata (2008), Pengaruh Nilai Pelanggan (Customer Value) Terhadap Loyalitas Pada Nasabah PT Bank Negara Indonesia Kantor Cabang Utama Medan
Jurnal

Alan D. Smith, William T. Rupp, (2003),"Strategic online customer decision making: leveraging the transformational power of the Internet", Online Information Review, Vol. 27 Iss: 6 pp. $418-432$

Josephine, Chu-chi, Liu, Ja-Shen Chen. Virtual Experiential Marketing On Online Purchase Intention. Proceedings of the 11th Annual Conference of Asia Pacific Decision Sciences Institute Hong Kong, June 14-18, 2006, pp. 325-333.

Journal of Hospitality \& Tourism Research, Vol. 32, No. 3, August 2008

Yuliastuti.Pengaruh penerapan experiential marketing terhadap kepuasan dan dampaknya pada niat membeli ulang di Mc. D Tunjungan Plaza dan Plaza Surabaya. FE UNAIR: 2005

Yi-Hua "Erin" Yuan, Chihkang "Kenny" Wu. Relationships Among Experiential Marketing, Experiential Value, and Customer Satisfaction. Journal of Hospitality \&amp; Tourism Research 2008; 32; 387 